\title{
Nutrition of the New Zealand White rabbit
}

\section{By J. Davidson and D. Spreadbury, Rowett Research Institute, Bucksburn, Aberdeen $A B 29 S B$}

Although the rabbit has boen included in this symposium on new farm animals, it appears to have been well-known in Britain for a thousand years. In a publication prepared for the British Association meeting in Edinburgh in 195I we learn (Fenton, 195I) that the rabbit was probably introduced around Norman times. It may even have come directly to Scotland from France in the twelfth century, for during the reign of David I, good relations were known to exist between the two countries. Rabbits were kept on the Isle of May in the Firth of Forth and skins were an important export. In fact, early records suggest that skin production may have been more important than meat production. Certainly rabbits have been farmed from early times in warrens from which some inevitably escaped to provide, in later centuries, a headache for the progressive farmer and a source of income for the progressive poacher until the introduction of myxomatosis in 1954 .

Improved selection and breeding in recent times has produced strains which can grow at rates comparable with the modern broiler chicken. The New Zealand White strain given an adequate diet can grow at over $40 \mathrm{~g} / \mathrm{d}$ between weaning and 8 weeks of age. This high rate of growth and the well-known prolificacy of the rabbit make rabbit-meat production worth considering as an alternative to red meat and poultry meat in the human diet. High biological efficiency has to be balanced in economic terms against the cost of accommodation and the intensive nature of the labour required in modern production units.

During this century the annual per capita consumption of rabbit meat in the UK rose from at least $0.6 \mathrm{~kg}$, the amount imported in 1913 (Ainsworth-Davis, 1924), to $2 \mathrm{~kg}$ in the early 1950 (Portsmouth, 1962 ) and dropped to about $0.4 \mathrm{~kg} 10$ years later as a result of the almost complete annihilation of the wild rabbit by myxomatosis, and a subsequent resistance by the housewife thereafter to the purchase of rabbit meat. The Commercial Rabbit Association estimates that current consumption is on the increase again, from about $0.25 \mathrm{~kg}$ in 1972 to $0.3 \mathrm{~kg}$ in 1973 . Only about one-third of the 15000 tons now consumed annually is produced in this country, the rest being imported mainly from China. These annual per capita consumption values for the UK compare with current values of $6 \mathrm{~kg}$ for France, $2 \mathrm{~kg}$ for Italy and I $\mathrm{kg}$ for Germany. It has been estimated that there is an appreciable market in Europe for quality rabbit meat and producers in this country are already exporting. However, if the industry is to expand, more information is needed on the nutrition of modern strains of rabbit both during the fast-growing stage of the young meat rabbit and during the reproductive cycle of the adult. 
From time to time various authorities throughout the world have drawn attention to the lack of scientific information on the nutrient requirements of the rabbit (Aitken \& King Wilson, 1962; (US) National Research Council, 1966), recommended allowances being based mainly on the results of experience in practice. In 1970 therefore it was decided to carry out some work at the Rowett Institute, in the first place on the fast-growing young rabbit, which consumes well over half the food in any production unit. For many years diet SG I described by Short \& Gammage (1959) has been the standard diet fed to both breeding and growing rabbits in the Small Animal Unit at the Rowett Institute. We have continued to use it as a standard of reference in experiments with the New Zealand White strain, which was introduced in 1971 after consultation with commercial producers and advisers. This diet supports growth rates of over $40 \mathrm{~g} / \mathrm{d}$ in the young New Zealand White rabbit compared with about $20 \mathrm{~g} / \mathrm{d}$ in the New Zealand Red $\times$ Lop cross previously maintained for experimental purposes. None of the experimental diets formulated recently have supported significantly higher growth rates.

In most livestock diets, provision of protein as a supplement to that already present in the energy-yielding cereal-roughage part of the diet is costly and savings made are more worthwhile in this than in any other area of formulation. Protein requirements are therefore generally considered first and in this instance it seemed reasonable to start with the requirement in the fast-growing stage of life for reasons already given.

\section{Optimum dietary protein level for the growing meat rabbit}

The Short \& Gammage (1959) diet, used for breeding females as well as growing young, contained about $200 \mathrm{~g}$ crude protein $(\mathrm{CP}$; nitrogen $\times 6 \cdot 25) / \mathrm{kg}$, a level probably higher than necessary for the growing meat rabbit, and so we wished first to ascertain the minimum content of good-quality protein which would support weight gains of over $40 \mathrm{~g} / \mathrm{d}$. The intention after that was to alter protein quality at this requirement level in order to find out whether amino acid balance was a factor of importance for this fast-growing mammal which practices coprophagy, a feature to be considered later. If it was not, cheaper protein concentrates, less well-balanced in amino acids, could be used in formulation.

Balance work. The experimental diets given in preliminary studies to rabbits in balance cages were based on oats and grass meal with increasing proportions of a good-quality white fish meal and adequate minerals and vitamins. These diets, shown in Table I, had CP concentrations ranging from I ro to $260 \mathrm{~g} / \mathrm{kg}$. Diet SG I (obtained from Oxoid Ltd, London) was given as a control. Each diet was fed to four individually-caged rabbits between weaning and 8 weeks of age. The results for both growth rate and food intake indicated that daily live-weight gain was maximal at dietary protein levels around $150 \mathrm{~g} / \mathrm{kg}$.

A study of the distribution of dietary $\mathrm{N}$ also indicated a need for $15^{\circ} \mathrm{g}$ protein $/ \mathrm{kg}$ diet. Above this concentration the amount of dietary protein apparently retained was almost constant. This then was the requirement of protein when almost half 
Table 1. Composition $(\mathrm{g} / \mathrm{kg})$ of diets given to rabbits in balance experiments

$\quad$ Ingredient
Ground oats
Ground oat husk
Grass meal
Wheat bran
Wheat middlings
Fish meal
Vitamin mixt
Mineral mix $f$
Bone meal
Distillers solubles, dried
Maize oil
Starch
Pellet binder

Chemical analysis

Crude protein

Crude fibre

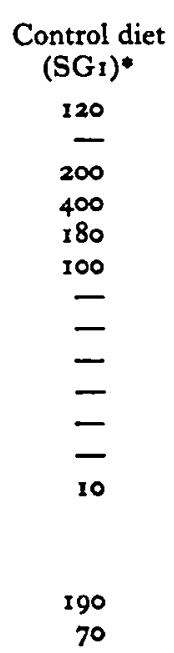

$\begin{array}{cr}\text { From } & \text { To } \\ 680 & 440 \\ 30 & 110 \\ 50 & 50 \\ - & - \\ - & - \\ 10 & 250 \\ 20 & 20 \\ 50 & 50 \\ 20 & 0 \\ 50 & 50 \\ 30 & 20 \\ 50 & 0 \\ 10 & 10 \\ & \\ 110 & 260 \\ 70 & 70\end{array}$

- Short \& Gammage (1959).

HIngredients were varied within the ranges shown.

†To provide per kg mixed diet the concentrations used by Adamson \& Fisher (r 973).

was provided by the basal part of the diet, mainly oats, and the rest by white fish meal. The metabolizable energy (ME) content for such diets was found to be about $10.5 \mathrm{MJ} / \mathrm{kg}(2.5 \mathrm{Mcal} / \mathrm{kg})$ and so the optimal $\mathrm{CP}: \mathrm{ME}$ ratio was about $14.3 \mathrm{~g} / \mathrm{MJ}$ (60 g/Mcal).

\section{Coprophagy}

At this point it is worth considering the special physiological feature of the rabbit which allows it to recycle digesta. Rabbit faeces can be differentiated into hard and soft, or 'green', faecal pellets. Most of the soft pellets, equivalent to about a half or more of the total faeces (Eden, 1940) are reingested direct from the anus. This recycled matter has spent some time in the caecum, where at least one-tenth of the basal energy requirements (Hoover \& Heitmann, 1972) of the animal can be obtained by fermentation. The resultant bacterial debris and residual digesta is enriched in $\mathrm{B}$ vitamins and contains about $250-300 \mathrm{~g} \mathrm{CP} / \mathrm{kg}$ dry matter. It might be argued that amino acid balance should thus be less critical in diets for the rabbit than it is for non-ruminants, and in fact work by Proto \& Gianini (1969) suggests that caecal activity can increase the proportions of methionine, threonine and tyrosine in the digesta.

It is worth noting however that the response to non-protein $\mathrm{N}$ in the form of urea seems to be poor (Olcese \& Pearson, 1948; King, 1971), perhaps indicating that easily available forms of $\mathrm{N}$ do not reach the caecum for incorporation into bacterial protein which can be recycled. 


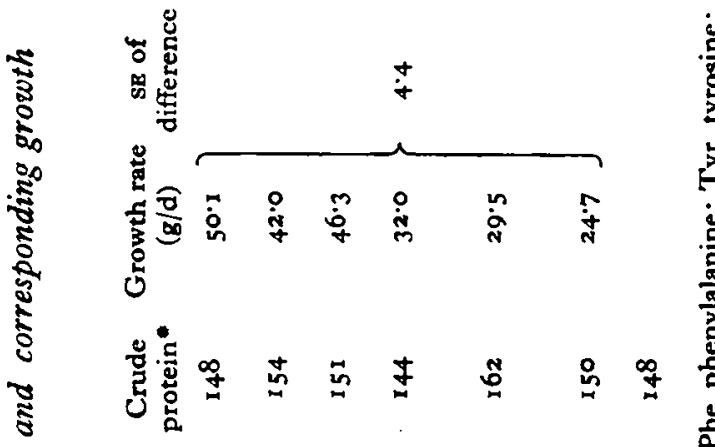

焉

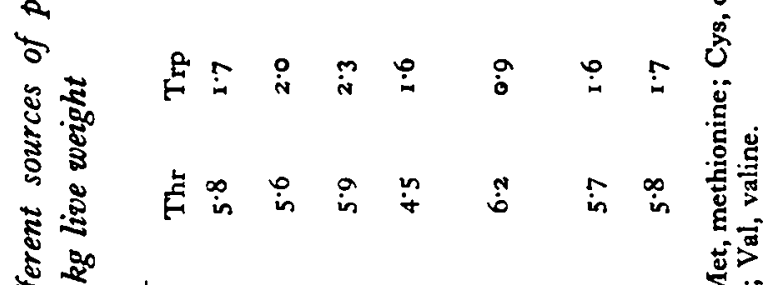

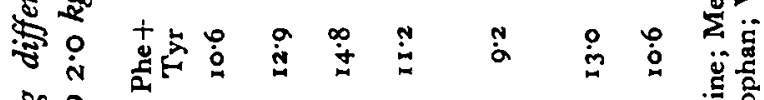

कर

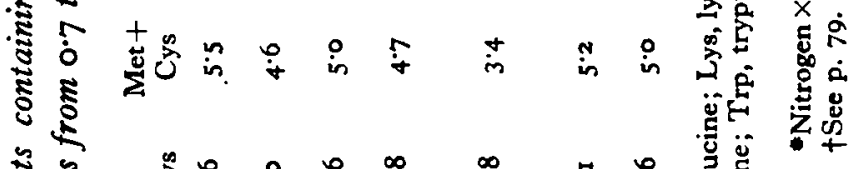

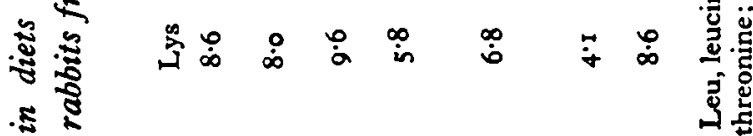

के

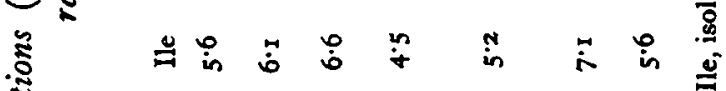

हैँ

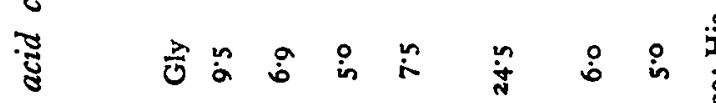

焉

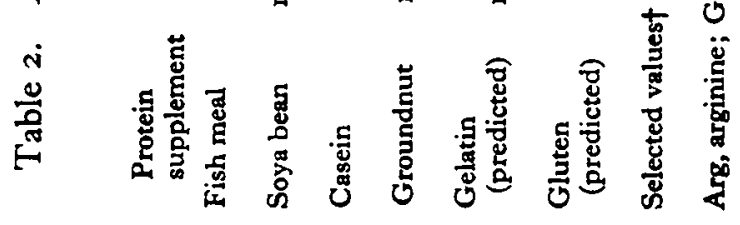




\section{The importance of protein quality}

If amino acid balance in the diet is important, then diets containing poor-quality supplements (as judged by diets for non-ruminants) such as gelatin and groundnut meal should not support such good growth as the fish-meal diets mentioned above. Diets were therefore formulated so as to provide protein concentrations of around $150 \mathrm{~g} / \mathrm{kg}$, of which $90 \mathrm{~g} / \mathrm{kg}$ was derived from fish meal, casein, soya-bean meal, groundnut meal, gelatin or maize gluten. The diets consisted of $(\mathrm{g} / \mathrm{kg}):$ ground oats 420 , oat husk 100 , grass meal 100 , maize oil 30 , vitamin premix 50 , mineral premix 100 , pellet binder 10 , starch plus protein concentrate, to provide $9 \circ \mathrm{g} \mathrm{CP}$, 190. To ensure that there would be no limitation owing to vitamins and minerals, the premixes supplied amounts given for purified diets by Adamson \& Fisher (1973). The growth rates obtained confirmed recent findings by McWard, Nicholson \& Poulton (1967), Gaman \& Fisher (1970), Cheeke (1971) and Cheeke \& Amberg (1972) that quality of protein in terms of amino acid balance was important for the growing rabbit. Fish meal, casein and soya-bean meal supported growth rates of over $40 \mathrm{~g} / \mathrm{d}$ whereas groundnut meal, gelatin and gluten supported rates of up to $3 \circ \mathrm{g} / \mathrm{d}$ only.

Table 2 shows the amino acid analyses for the experimental diets as well as the growth rates attained. From the two diets supporting the highest rates of growth, values were selected above which it was considered that individual amino acid requirements were unlikely to lie. The values for sulphur amino acids should be treated with some caution because no allowance was made for losses during acid hydrolysis prior to analyses. We regard the values for cystine and methionine as minimal and possibly low by $10 \%$.

Table 3. Analyses of diets and growth rates of rabbits given groundnut diets having adequate lysine (Lys) and increasing levels of methionine plus cystine (Met + Cys)

\begin{tabular}{|c|c|c|c|c|c|c|}
\hline & \multicolumn{4}{|c|}{ Experimental diets" } & \multirow{2}{*}{$\begin{array}{c}\text { Control diet } \\
\text { (SGI)t }\end{array}$} & \multirow{2}{*}{$\begin{array}{c}\text { SE of } \\
\text { difference }\end{array}$} \\
\hline & $\mathbf{A}$ & $\mathbf{B}$ & C & D & & \\
\hline Lys (g/kg) & 10 & Io & 10 & 10 & - & \\
\hline $\begin{array}{l}\text { Met + Cys }(g / k g) \\
\text { Growth rate }(g / d)\end{array}$ & 3.9 & 4.9 & $5 \cdot 2$ & $6 \cdot 6$ & - & \\
\hline between 0.7 and $2.0 \mathrm{~kg}$ & $28 \cdot 6$ & $34 \cdot 2$ & $33 \cdot 7$ & $35 \cdot 4$ & $4 I \cdot 5$ & $x \cdot 6$ \\
\hline
\end{tabular}

When a diet containing groundnut meal was now given with a supplement of lysine alone, there was no significant effect on growth rate. However, lysine plus methionine addition did improve growth rate, thus indicating that methionine was the limiting amino acid. With the lysine level raised to $10 \mathrm{~g} / \mathrm{kg}$, and thus above what was considered to be requirement value, three levels of methionine were added to a basal diet to give four dietary concentrations between 4 and $7 \mathrm{~g} / \mathrm{kg}$. Table 3 shows that the growth rate supported by the $4 \mathrm{~g} / \mathrm{kg}$ level was significantly less than by the 
other three levels, and it was concluded that at least $5 \mathrm{~g}$ methionine plus cystine $/ \mathrm{kg}$ diet was necessary. A similar growth experiment in which the methionine plus cystine concentration was raised to a measured value of $6 \mathrm{~g} / \mathrm{kg}$ showed that the requirement for lysine was approximately $9 \mathrm{~g} / \mathrm{kg}$ (Table 4 ).

Table 4. Analyses of diets and growth rates of rabbits given groundnut diets having adequate methionine plus cystine (Met $+C y s)$ and increasing lysine (Lys)

\begin{tabular}{|c|c|c|c|c|c|c|}
\hline & \multicolumn{4}{|c|}{ Experimental diets" } & \multirow{2}{*}{$\begin{array}{l}\text { Control diet } \\
\text { (SGI) } \uparrow\end{array}$} & \multirow{2}{*}{$\begin{array}{c}\text { SE of } \\
\text { difference }\end{array}$} \\
\hline & A & $\mathbf{B}$ & C & D & & \\
\hline $\begin{array}{l}\text { Lys }(\mathrm{g} / \mathrm{kg}) \\
\text { Met }+ \text { Cys }(\mathrm{g} / \mathrm{kg}) \\
\text { Growth rate }(\mathrm{g} / \mathrm{d})\end{array}$ & $\begin{array}{l}5 \cdot 0 \\
6\end{array}$ & $\begin{array}{l}5 \cdot 7 \\
6\end{array}$ & $\begin{array}{l}7 \cdot I \\
6\end{array}$ & $\begin{array}{l}9.4 \\
6\end{array}$ & - & \\
\hline between 0.7 and $2.0 \mathrm{~kg}$ & $32 \cdot 4$ & $39 \cdot 6$ & $4 x \cdot 6$ & $47 \cdot 2$ & $49 \cdot 4$ & $2 \cdot 0$ \\
\hline
\end{tabular}

The selected value of $7 \mathrm{~g} / \mathrm{kg}$ for arginine in Table 2 is somewhat lower than values of 9-10 g/kg suggested by McWard et al. (1967), Cheeke (1971) and Adamson \& Fisher (1973). It is reasonable, in fact, that the rabbit should have a low arginine requirement because it has an active urea cycle and should be able to synthesize at least some of its requirements. It is difficult to formulate natural diets low in arginine and first attempts at pelleting and feeding purified diets based on casein and starch proved unsuccessful. However, the problems were eventually overcome and a diet based on casein, dextrin, oat husk and grass meal, containing less than $6 \mathrm{~g}$ arginine $/ \mathrm{kg}$, was accepted by the rabbits. Growth rates of over $40 \mathrm{~g} / \mathrm{d}$, not significantly different from the growth rate of $43 \mathrm{~g} / \mathrm{d}$ on diet $S G_{1}$, were obtained whether or not supplemental arginine was added. This suggested that the arginine requirement for young rabbits is indeed much lower than indicated hitherto, and that it was probably less than $6 \mathrm{~g} / \mathrm{kg}$ diet.

The set of values which we are using meanwhile as a basis for further study of the amino acid needs of the fast-growing meat rabbit up to slaughter at $2.5 \mathrm{~kg}$ is therefore $(\mathrm{g} / \mathrm{kg} \mathrm{diet}): \mathrm{CP} 15^{\circ}$, arginine $6 \cdot 0$, glycine $5^{\circ} 0$, histidine $2 \cdot 8$, isoleucine $5^{\cdot 6}$, leucine 10.4 , lysine 9.0 , methionine plus cystine 5.5 , phenylalanine plus tyrosine $10 \cdot 6$, threonine $5 \cdot 8$, tryptophan $\mathrm{I} \cdot 7$, valine $7 \cdot \mathrm{I}$.

In addition to further study of the amino acid requirements of the growing rabbit, there is a need for work on protein and amino acid requirements of the doe during gestation and lactation. From the compounders' point of view and probably also the producer's point of view, it is convenient to feed the same diet to breeding and growing rabbits and this is in general the situation in this country. It seems likely that daily protein requirements in late gestation and at the start of lactation will be higher than during the first phase of growth, but energy requirement is probably also higher. Comprehensive studies of amino acid requirements of the breeding doe do not appear to have been carried out, but from unpublished information quoted 
by the (US) National Research Council ( 1966 ) it appears that over-all protein requirements as a proportion of dietary digestible energy are similar for the young rabbit and the breeding, lactating doe, thus suggesting that so long as the intake of diet by the breeding doe is not restricted by diet density or palatability factors, then the same diet may well be used for all stock. However, we hope to carry out work on the breeding doe in the near future to obtain further information on such points.

\section{Energy}

Maintenance and growth. According to Axelsson (1949), the daily maintenance requirement is almost linear from $0.80 \mathrm{MJ}$ at $\mathrm{r} .5 \mathrm{~kg}$ live weight to $\mathrm{I}^{\circ} 46 \mathrm{MJ}$ at $4 \mathrm{~kg}$ live weight. The same author has shown that for each $\mathrm{kg}$ live weight gain, the ME required is between $16.3 \mathrm{MJ}$ at 8 weeks and $43 . \mathrm{M} \mathrm{MJ}$ at 24 weeks of age. If we apply these values in our own circumstances to stock growing at $45 \pm 5 \mathrm{~g} / \mathrm{d}$, the daily energy requirements given in Table 5 can be predicted for live weights of $I, I \cdot 5$ and $2.0 \mathrm{~kg}$. Balance work at the Rowett Institute indicates that the requirement at I kg is approximately correct for our New Zealand White strain.

Table 5. Daily metabolizable energy (ME) requirements of the growing meat rabbit, after Axelsson (1949)

\begin{tabular}{|c|c|c|c|c|c|}
\hline $\begin{array}{l}\text { Live weight } \\
\text { (kg) }\end{array}$ & $\begin{array}{l}\text { Approx. age } \\
\text { (weeks) }\end{array}$ & $\begin{array}{l}\text { Maintenance } \\
\text { ME (MJ) }\end{array}$ & $\begin{array}{c}\text { Production } \\
\text { (45 g/d) } \\
\text { MB (MJ) }\end{array}$ & $\begin{array}{c}\text { Total } \\
\text { ME (MJ) }\end{array}$ & $\begin{array}{c}\text { Daily requirement of } \\
\text { diet having } \\
10.5 \mathrm{MJ} \mathrm{Mz/kg} \\
\text { (g) }\end{array}$ \\
\hline 1.0 & 6 & 0.63 & 0.58 & $I \cdot 2 I$ & 115 \\
\hline $\begin{array}{l}1 \cdot 5 \\
2 \cdot 0\end{array}$ & $\begin{array}{l}7.5 \\
9\end{array}$ & $\begin{array}{l}0.80 \\
0.96\end{array}$ & $\begin{array}{l}0.70 \\
0.81\end{array}$ & $\begin{array}{l}1.50 \\
1.77\end{array}$ & $\begin{array}{l}143 \\
168\end{array}$ \\
\hline
\end{tabular}

Pregnancy. It is generally agreed that overfatness is to be avoided in the breeding doe as in other livestock, and the recommendation by Sandford (1957) of maintenance requirement plus one-third at the start of pregnancy, rising to twice maintenance at the end of pregnancy, seems reasonable, i.e. $2 \cdot 0-3 \cdot 0 \mathrm{MJ} / \mathrm{d}$ for a $4 \mathrm{~kg}$ doe.

Lactation. A $4 \mathrm{~kg}$ doe in early lactation will require a maintenance allowance of I.5 MJ ME plus an allowance for milk. In our experience the New Zealand White doe can secrete up to $250 \mathrm{~g}$ milk daily at peak lactation. The mean amount secreted over the peak period during the $3^{\text {rd }}$ and $4^{\text {th }}$ weeks of lactation is about $200 \mathrm{~g}$ daily. The gross energy value of this is about 8-12 MJ/kg (Aitken \& King Wilson, 1962). If we take $8 \mathrm{MJ} / \mathrm{kg}$, assume a partial efficiency of conversion of digestible energy to milk energy of $45 \%$, similar to that found (Leitch \& Godden, I94I) for a cow yielding $40.91(9 \mathrm{gal}) / \mathrm{d}$, and $\mathrm{ME}$ as $93 \%$ of digestible energy, then the ME required is about $16.0 \mathrm{MJ} / \mathrm{kg}$ milk secreted. Thus, at peak production of $250 \mathrm{~g} / \mathrm{d}$ during weeks 3-4, $4^{\circ} \mathrm{MJ}$ of $\mathrm{ME}$ or about 3 times maintenance requirement will be required daily in addition to the $\mathrm{I} .5 \mathrm{MJ}$ for maintenance. Intake of a diet containing $10.5 \mathrm{MJ} / \mathrm{kg}$ would have to be over $500 \mathrm{~g} / \mathrm{d}$, and this is seldom achieved. Axelsson (1949) recommended 3.3 times maintenance as the allowance for milk production during weeks 3-4.

$34(1) 6$ 


\section{Effect of fibre in the ration}

It is commonly said that the rabbit needs at least $14^{\circ} \mathrm{g}$ crude fibre $/ \mathrm{kg}$ in the ration to ensure efficient functioning of the alimentary tract, but recent evidence (Heckmann \& Mehner, 1970) indicates that $80-90 \mathrm{~g} / \mathrm{kg}$ is adequate, and our own experience would confirm this. In a series of diets formulated to assess the effect of increased fibre on food intake and growth, a basal diet of oat meal, grass meal and fish meal was diluted with up to $400 \mathrm{~g}$ roughage $/ \mathrm{kg}$ in the form of oat husk or cellulose fibre. Table 6 shows that as the roughage in the diet increased, dry matter ingested also increased, and $M E$ intake was relatively constant. Digestibility of fibre was found to be low, at $0.05-0 \cdot 10$. Apart from the diet containing $400 \mathrm{~g}$ oat husk $/ \mathrm{kg}$, growth rates were normal even on the basal ration containing only $30 \mathrm{~g}$ crude fibre $/ \mathrm{kg}$. However, a tendency to scouring was noted on the basal diet and a subsequent experiment showed that with $60 \mathrm{~g}$ crude fibre $/ \mathrm{kg}$, scouring was eliminated. Our conclusion is that within wide limits, certainly between $50 \mathrm{~g}$ and $200 \mathrm{~g}$ crude fibre $/ \mathrm{kg}$, the young rabbit is able to adjust intake according to its requirement for $\mathrm{ME}$.

Table 6. Effect on intake of metabolizable energy (ME) by rabbits of dietary fibre in the form of cellulose $(a)$ and oat-husk (b) diets

\begin{tabular}{|c|c|c|c|c|c|c|c|c|c|c|c|}
\hline \multirow[t]{2}{*}{$\begin{array}{c}\text { Dietary } \\
\text { roughage } \\
(\mathrm{g} / \mathrm{kg})\end{array}$} & \multicolumn{2}{|c|}{$\begin{array}{l}\text { Dietary } \\
\text { Mz found } \\
\text { (MJ/kg DM) }\end{array}$} & \multicolumn{2}{|c|}{$\begin{array}{c}\text { Crude fibre } \\
(\mathrm{g} / \mathrm{kg})\end{array}$} & \multicolumn{2}{|c|}{$\begin{array}{c}\text { Mean DM } \\
\text { intake over } \\
3 \text { weeks } \\
\text { (g/d) }\end{array}$} & \multicolumn{2}{|c|}{$\begin{array}{c}\text { MB intake } \\
(\mathrm{MJ} / \mathrm{d})\end{array}$} & \multicolumn{2}{|c|}{$\begin{array}{l}\text { Growth rate } \\
(\mathrm{g} / \mathrm{d})\end{array}$} & \multirow[t]{2}{*}{$\begin{array}{c}\mathbf{S B} \\
\text { of } \\
\text { difference }\end{array}$} \\
\hline & a & b & a & b & a & b & a & b & $\mathbf{a}$ & b & \\
\hline 0 & 12.9 & 12.9 & 30 & 30 & $8 I$ & 81 & 1.05 & 1.05 & 45.6 & 45.6 & 7 \\
\hline 200 & 12.0 & $12 \cdot 0$ & 80 & 130 & 97 & 89 & $x \cdot 16$ & 1.06 & $46 \cdot 3$ & 45.9 & \\
\hline 300 & 10.3 & $9 \cdot 7$ & 110 & 190 & 103 & 100 & 1.06 & 0.97 & $46 \cdot 1$ & $43 \cdot 5$ & \\
\hline 400 & 8.7 & $9 \cdot 8$ & 140 & 230 & 114 & 98 & 0.99 & 0.96 & 46.5 & 39.3 & \\
\hline
\end{tabular}

DM, dry matter.

\section{Vitamin and mineral requirements}

There is little information in addition to that summarized by Aitken \& King Wilson (1962).

The rabbit does not seem to require ascorbic acid in the diet and under normal feeding conditions coprophagy would be expected to make it relatively independent of dietary B vitamins. A recent paper by Payne, Donefer \& Baker (1972) indicates that daily vitamin A requirement is greater than $14 \mu \mathrm{g}$ retinol $/ \mathrm{kg}$ live weight, no level used in this study being fully satisfactory. Vitamin A precursor and vitamin D would normally be derived in adequate amounts from grass meal and roughage in rabbit diets. It is probably worth recalling that Short \& Gammage (1959) modified the standard diet of Bruce \& Parkes (1946) to avoid the use of components prone to become rancid and thus oxidize vitamins such as $A$ and $E$ during storage.

Chapin \& Smith (1967a) found that the calcium requirement of the New Zealand White meat rabbit was about $4 \mathrm{~g} / \mathrm{kg}$ diet for maximum bone calcification, but 2.5 
$\mathrm{g} / \mathrm{kg}$ was adequate for normal growth. Phosphorus requirement of the young rabbit was $2.2 \mathrm{~g} / \mathrm{kg}$ according to Mathieu \& Smith (I96I). A Ca :P ratio of I : I or $2:$ I would appear to be best but up to $12: 1$, i.e. $45 \mathrm{~g} \mathrm{Ca} / \mathrm{kg}$, was not detrimental (Chapin \& Smith, $1967 b)$.

Until such time as we can be more certain of the requirements for vitamins and trace minerals, we have, at the Rowett Institute, taken the precaution of adding to all diets the concentrations used by Adamson \& Fisher (1973).

\section{Conclusions}

The nutrient requirements of the rabbit are still inadequately defined. More is now known of the requirements for amino acids and energy than for minerals and vitamins, the latter perhaps being more difficult to define owing to the rabbit's peculiar habit of coprophagy.

The rabbit work at the Rowett Research Institute was supported by a grant from the Agricultural Research Council.

\section{REFERENCES}

Adamson, I. \& Fisher, H. (1973). F. Nutr. 103, 1306.

Ainsworth-Davis, J. R. (1924). Resources of the Empire Series: Meat, Fish and Dairy Produce. London: Benn.

Aitken, F. C. \& King Wilson, W. (1962). Tech. Commun. Commonto. Bur. Anim. Nutr. no. I2.

Axelsson, J. (1949). Proc. 5th Congr. int. Zootech., Paris.

Bruce, H. M. \& Parkes, A. S. (1946). F. Hyg., Camb. 44, 50r.

Chapin, R. E. \& Smith, S. E. (1967a). F. Anim. Sci. 26, 67.

Chapin, R. E. \& Smith, S. E. (1967b). Cornell Vet. 57, 480.

Cheeke, P. R. (1971). Nutr. Rep. int. 3, 123.

Cheeke, P. R. \& Amberg, J. W. (1972). Nutr. Rep. int. 5, 259.

Eden, A. (1940). Nature, Lond. 145, 36.

Fenton, E. W. (1951). In Scientific Survey of South-eastern Scotland [C. J. Robertson, editor]. Edinburgh: British Association.

Gaman, E. \& Fisher, H. (1970). Nutr. Rep. int. I, 57.

Heckmann, F. W. \& Mehner, A. (1970). Arch. Geflügela. Kleintierk. 19, 29.

Hoover, W. H. \& Heitmann, R. N. (1972). J. Nutr. 102, 375.

King, J. O. L. (1971). Br. vet. F. 127, 523.

Leitch, I. \& Godden, W. (1941). Tech. Commun. imp. Bur. Anim. Nutr. no. 14.

McWard, G. W., Nicholson, L. B. \& Poulton, B. R. (1967). F. Nutr. 92, i 18.

Mathieu, L. G. \& Smith, S. E. (196r). F. Anim. Sci. 20, 510.

National Research Council (1966). Nutrient Requirements of Domestic Animals No. 9. Rabbits. Washington, DC: National Academy of Sciences/National Research Council.

Olcese, O. \& Pearson, P. B. (1948). Proc. Soc. exp. Biol. Med. 69, 377.

Payne, A. S., Donefer, E. \& Baker, R. D. (1972). Can. Y. Anim. Sci. 52, 125.

Portsmouth, J. I. (1962). Commercial Rabbit Meat Production. London: Iliffe.

Proto, V. \& Gianini, L. (1969). Produz. Anim. 8, 203.

Sandford, J. C. (1957). The Domestic Rabbit. London: Lockwood.

Short, D. J. \& Gammage, L. (1959). J. Anim. Techns Ass. 9, 62. 